\title{
Andreas Jaszlinsky versus Aristotle \\ The interface of Facts and Logic: Reflections \\ on the Origin of Life in the Work of the Trnava \\ Jesuit in the $18^{\text {th }}$ Century
}

Andrej Démuth - Erika Juríková

(Comenius University, Bratislava; Trnava University, Trnava)

\begin{abstract}
Reflections on the Origin of Life, by Andreas Jaszlinsky, represents a remarkable symbiosis of the empirical knowledge of the period and the rational education provided to Jesuits in the mid- $18^{\text {th }}$ century. In this study we attempt to offer a context for the consideration of ovism and preformationism, primarily based on Aristotle and the scientific research of one of the leading philosophers of the Jesuit Universitatis Tyrnaviensis. Andreas Jaszlinsky, a University Professor and Jesuit, deals with this topic in his work Institutiones physicae. Physica generalis (1761). This text, only fragments of which have been translated into Slovak, is an important document about the state of knowledge of the period but also about the need for intellectuals to think scientific theories (in this case, materialism) through to their consequences and take a position in regard to them.
\end{abstract}

\section{Keywords}

Aristotle; baroque science; Society of Jesuits; historical Trnava University / Universitas Tyrnaviensis (1635-1777); Andreas Jaszlinsky; ovularism

The article is a partial output of the grant VEGA 1/0749/20. This paper is a supplemented and revised version of the paper: Andrej Jaslinský a jeho Základy fyziky (Andrej Jaszlinsky and His Fundamentals of Physics) that was published in Slovak as part of: Antológia z diel profesorov pôsobiacich na Trnavskej univerzite (1635-1777) (Anthology of the Works of Professors Working at the Universitas Tyrnaviensis, 1635-1777, Trnava: Trnava University 2016). 
The establishment of Trnava University in 1635 was part of a rather extensive movement. On one hand, we had the transformation of the educational process and the specification of new educational disciplines and methods, but on the other, new Jesuit colleges and universities emerged as a partial counter-measure against the expansion of Protestant education. Thus, the role of Trnava University was to provide high-quality education in the domestic Hungarian environment to preserve and strengthen the religious and political system while helping to build the future bureaucratic apparatus of a state loyal to the ruling Habsburg dynasty.

The educational process at the University drew from the traditions and institutional structures of the medieval universities, while at the same time responding to modern achievements such as the printing press, new discoveries and theories, as well as modern pedagogical approaches. In terms of the traditional division of subjects, Philosophy, specifically Logic, Rhetoric and General Philosophy, was mostly studied during the first stage of a university education. The term General Philosophy predominantly meant metaphysics, but in the $18^{\text {th }}$ century, this term was used for Natural Philosophy which was a traditional discipline of Renaissance and modern philosophizing.

Treatises on the biology of animals and man represented a fundamental part of the contemporary philosophia naturalis. In particular, the series of books by Aristotle: Tw̃v

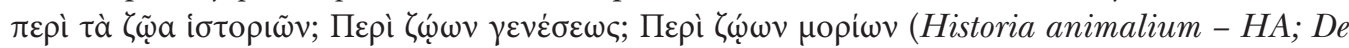
Generatione Animalium; De Partibus Animalium) provided the base for the knowledge in this field. Later, commentaries on these books were added and some other independent treatises. Although, in the seventeenth and eighteenth centuries, the character of natural philosophy probably changed in a most significant way (contrary to the stability of other Aristotelian disciplines such as logic, metaphysics and onomastics), biology did not undergo such dramatic change as physics, astronomy and alchemy. Nevertheless, in this study we shall especially focus on a presentation of the Jesuit reception of the dynamics in the development of biology, as encountered in the Latin works Institutiones physicae, Physica generalis and Physica particularis by the Hungarian Jesuit and professor of the historical Trnava University (1635-1777), Andreas Jaszlinsky. This work came out in 1761 (first edition 1756), from the Typis Academicis Societas Iesu Universitatys Tyrnaviensis in Trnava (Tyrnavia, Nagyszombat, Tyrnau), where Jaszlinsky lectured. This was shortly after the monarch Maria Theresa issued a decree related to the reform of university education in the Kingdom of Hungary, which replaced Aristotelian physics with Newtonian physics. Jaszlinsky's work documents the nature of the change in thinking that was taking place, the departure from Aristotelianism, as well as the Jesuit education and methods of reasoning in a field of study which would not seem to be particularly typical of the Jesuits - biology. In this study we shall especially focus on the fourth dissertation, part 1 (De animatis), which deals with animals and their origins. It is here in particular that the Janus-faced character of the Jesuit history of the study of the natural sciences is most clearly reflected. ${ }^{1}$

1 Cf. Blum (2012: pp. 113-138). 
In the early eighteenth century we can observe a boom in the foundation of botanical gardens, ${ }^{2}$ observatories, ${ }^{3}$ pharmacies ${ }^{4}$ and anatomical theatres at universities and an overall growth of interest in plants and animals. Nonetheless, instead of conducting rich research and experimentation, the majority of the works on biology and zoology published at that time were still subjugated by the Aristotelian, mainly rationalist classification and description of animals until well into the second half of the eighteenth century. In particular Aristotle preferred the systematic organisation and classification of animals through their characteristics rather than the causes of them. His work in this field was based on the search for identical and differing characteristics of their body parts (HA - Books I to IV); differences in their ways of life and types of activities (HA - V, VI, VII and IX); and differences between their special signs (HA - VIII). Thus the History of Animals (I) was a study of the classification of animals and parts of the human body; (II) various parts of red-blooded animals; (III) internal organs, including the reproductive system, veins, tendons, bones; (IV) animals without blood (invertebrates) - cephalopods, crustaceans, etc.; (V) the spontaneous and sexual reproduction of invertebrates; (VI) the reproduction of birds, fish and four-legged creatures; (VII) the reproduction of man; (VIII) the character and habits of animals, food, migration, health, illnesses and the influence of the climate; (IX) the mutual relationships between animals and means connected to the supply of food.

Generally it may be noted that classification was the principal concern of the biology of the classical, medieval and early modern periods. For example, in the fourth edition of Wilhelm Scribonius' textbook from 1600, we can find live creatures classified as rational or irrational as those that live in the water and those that live on the ground, into reptiles and four-legged creatures, into monotrematous and viviparous, even-toed and odd-toed ungulates, ${ }^{5}$ with no further more substantial description or theological

2 The reasons behind the foundation of botanical gardens go back to the Middle Ages, they were to meet the needs of faculties of medicine so that sufficient amounts of herbs and berries with healing effects were available for medical and pharmacological purposes, as well as for research. A small pharmacy had operated in the premises of the university even before its official foundation in 1635. Cf. Pivovarčiová \& Schwarc (2014: pp. 269-277). In the modern period, in addition to a medicinal garden, the concept of exotic and educational gardens was brought to the fore, as well as the organisation of a garden as a place for pleasant rest in the open air. Cf. McClellan III, "Scientific Institutions and the Organization of Science". The botanical garden of Trnava University, which was visited by both teachers and students in order to rest, was located behind the sugar refinery next to the old cemetery and was founded in 1770 as part of the Faculty of Medicine. Zborovjan (2014: pp. 279-285).

3 The observatory - a five-storey Baroque tower - was opened at Trnava University in 1756 (in the same year that Jaszlinsky was writing his work in the same year). It was located in the north-east corner of the university complex (at the corner of Jerichova and Jeruzalemská streets). Hološová \& Žažová (2013).

4 The university pharmacy was officially founded in 1636. Pivovarčiová \& Schwarc (2014: pp. 269-277). The Faculty of Medicine was founded no earlier than 1769. Kopecký (2014: pp. 269-277).

5 Aristotle's division presupposes the following: live creatures with blood (Enaima) - viviparous four-legged creatures, birds, monotrematous four-legged creatures and fish; and invertebrae (Anaima) - Malakia (mollusks), Malakostraka (soft-shelled, today cephalopods and crustaceans), Entoma (insects) and Ostrakodermata (testaceans: e.g. radiata, sponges and others). 
explanation. ${ }^{6}$ Other authors of the period worked in a similar fashion ${ }^{7}$ and Jaszlinsky's text is no exception.

However, his research followed a remarkable methodological approach and drew some rather interesting conclusions.

Andrej Jaszlinsky was not only one of the scientifically most important representatives of philosophy at the historical Trnava University (1635-1777), but also in the whole of the Kingdom of Hungary. He lived in a period when the work and creativity of the philosophers in Trnava was relatively unobstructed and progressive; we can observe both progressive and conservative tendencies in his works. It is obvious that in his treatises that dealt with physics he does not only move within the restraints of scholastic Aristotelianism and Thomism but instead also considers and gives preference to new scientific methods of research. After Bacon, Boyle and Newton he fully realised that knowledge of nature is based on experience and observation using the senses. Thus, research into nature should, in particular, be conducted through observation, experience and experiment, but also through deliberation and the search for evidence. Although the Jesuits, observing the studium rationale, mostly did not carry out research into the natural-sciences themselves, they often responded to the experiments of their contemporaries. Jaszlinsky's text contains a number of references to various, even very current and relevant, studies of his period; we can find traces of the work of Thomas Muffet, Friedrich Christian Lesser, Antonio Vallisneri, Nicolaas Hartsoeker, Antonie van Leeuwenhoek, William Harvey, Alexis Littré, Olaus Magnus, Otto Frederik Müller, Francesco Redi, John Ray and many others. This creates an image of Jaszlinsky as a knowledgeable and well-read scholar, thus also documenting the high quality of the university library and that his research was relatively up to date.

One of the most interesting questions in this work is provided by Section 2, dedicated to the origin of animals. In the introduction Jaszlinsky writes that no animal is born from nothing. The Aristotelian tradition believed in the theory of (self-) fertilisation, but the onset of mechanistic science and biology suggested the option that live organisms may originate from nothing more than a union of matter, thus essentially from nothing. Arguing against this opinion Jaszlinsky refers to Redi's experiments and shows that generatio ex nihilo does not exist. Under the influence of works by Regnier de Graaf, a naturalist in the late seventeenth century, the existence of sex cells was already apparent (Graafian follicles) although the ovum of mammals was not yet described wholly correctly. In his text Jaszlinsky referred to the works and opinions of William Harvey, who continued the embryological work of his teacher Fabricius ab Aquapendente. Harvey believed that life originated as a result of the fertilisation of an egg (omne vivum ex ovo). The fundamental

6 Paraphrased according to: Blair (2008: p. 369).

7 However, to be wholly correct with respect to the given period, we have to state that it was in the first half of the $18^{\text {th }}$ century that other types of classification originated (especially in botanics - after John Ray - Carl Linné - a graduate of Lund and later the university in Uppsala wrote the manuscript "Systema Naturae" in 1737 - a seven-page study containing binomic nomenclature) and discussions also arose with regard to the classification used in zoology. 
question asked by naturalists in that period was from what and in what manner the individual life of any live creature originated.

As early as the beginning of the $17^{\text {th }}$ century, Preformationism became a theory that was generally accepted by scientists. According to Joseph Needham, this might have mainly been due to the writings of Malpighi (De formation pulli in ovo, 1667 in: Opera Omnia, 1686 [London]: apud Robertum Scott), Jan Swammerdam (Miraculum nature, sive, Uteri muliebris fabrica. Lugduni Batavorum [Leiden]: apud Severinum Matthæi, 1672) and Charles Bonnet (Contemplation de la Nature. [Amsterdam]: Marc-Michel Ray) as well as embryologists who declared they had seen tiny human forms in gametes.

Opinions on the significance of sex cells differed, with two basic concepts being prevalent. Harvey (Anatomical exercitations concerning the generation of living creatures to which are added particular discourses of births and of conceptions. 1651 [London]: apud James Young) and others believed that it was only the egg that was necessary for the origination of life (Ex ovo omnia!). It was solely within the egg that all the essential determinants for the origination of a new creature was present. This preference given to the role of female sex cells may be termed ovism (championed by ovists). Jaszlinsky's text, however, shows that he was also well aware of the opposing theory - animalculism. Animalculists (e.g. Anton van Leeuwenhoek (De Natis e semine genital Animalculis - 1677, letter to the Royal Society), Nicholas Hartsoecker (Essai de dioptrique, 1694, [Paris]) and Wilhelm Gottfried Leibniz (Lehr-Sätze über die Monadologie, ingleichen von Gott und seiner Existentz, seinen Eigenschafften und von der Seele des Menschen etc. wie auch Dessen letzte Vertheidigung seines Systematis Harmoniae praestabilitae wider die Einwürffe des Herrn Bayle. 1720 Meyers sel. Witwe Buchhandlung in Jena, Frankfurt und Leipzig)) believed that the creative, developmental force was stored in the spermatozoa (sperm) and that the egg only served as nourishment. In objection to this theory, our author argues, in particular, with the illogicality of the excessive number of sperm and the questionable existence of "diminutive worms" in some live creatures. It seems that he rather takes the side of the ovularists.

We can hardly avoid the suspicion that Jaszlinsky was an ovularist especially after we read his resolute statement that "Omnia animalia nascuntur ex ovis faecundatis suae speciei animalium." The first part of the thesis about the necessity for the existence of an egg in the origination of a new life is self-evident. Jaszlinsky conscientiously fights against the mechanistic materialism which was growing stronger and which culminated, in the second half of the eighteenth century, in the works of Diderot and d'Holbach (La Mettrie died in 1751), although he does not mention them in his treatise. Similarly he does not mention Buffon and Needham, who presented theories on the origin of life and pre-existence, partly compatible with materialism. Evidently what he was after, though, was the rejection of the mechanistic or any other type of materialism which would suggest that

8 Jaszlinsky (1761: 551). Jaszlinsky already believed this when he justified the origin of plants in his botany. Here, he drew from the works of Francesco Redi from 1668 (Esperienze intorno alla generazione degl'insetti), Marcell Malpigi and Antonio Vallisneri. However, (as it seems) Jaslinský rejected the Preformationism theory, as, during his own observations, he had found that germ cells did not contain all the features of the adult organism and he documented this in his drawings of plant tissues through his observations made through a microscope. 
life, as such, or the life of an individual, may originate as a result of a common union, or, so to speak, from nothing. Nam 1. reliqua, de quorum ovulis constat, ex iis nascuntur, igitur etiam illa, de quovum ovulis oculi nostri hebetes non testantur. Nam haec iuxta n. 549 non generantur ex putri, nec fortuito particularum concursu, neque dici possunt a Deo solo produci. ${ }^{9}$ Thus, even the smallest creatures, insects, and even minuscule organisms that could be observed using Leeuwenhoek's microscope have at their disposal (although tiny and indiscernible with the naked eye) eggs which are the basis and a condition for their reproduction.

However, the other part of Jaszlinsky's statement is rather more complicated. What does he mean when he says "fertilised"? At first sight it may seem that he understands this to be the union of an egg with a spermatozoon. In text No. 553, however, he states that foetus in viviparis non generari praecise ex commixtione seminum maris et foeminae, huius in utero, quod Pythagoras, Plato ac Aristoteles existimabant; neque inde animalis corpusculum in utero matris fieri, quod particulae seminales sic in eo compingantur et copulentur, ut quae ex parentum cerebro decerptae fuerant, cerebrum, quae ex ossibus, ossa et cetera constituant, quod Hippocrates voluit existimans semen animalis non aliud esse, quam complexum particularum omnibus ex eius membris decerptatum ac in uterum transmissarum; neque demum inde quod ex innumeris vermiculis exilissimis, spermaticis dictis, semini masculino innatantibus unus vel plures in matris uterum delapsi uteri membranis adhaereant, vel in ovarium pervadentes uni vel pluribus ovulis se inserant, donec evolutis sensim partibus sub forma embrionis certi animalis se sistant et in novum velut animal convertantur. ${ }^{10}$

On the other hand, Jaszlinsky added: "Nisi enim a femine masculino ovula foemellarum faecundentur, ut certum est, sterilia evadunt." ${ }^{11}$ So, what should we think about all this?

It is obvious that we acknowledge the role of the egg (conditio sine qua non), but what is the role of sperm? Jaszlinsky argues against the union of sex cells with an attack on animalculism and its concept of heredity. He believes that if the male sex cells alone were to be the source of life, the progeny of a crippled father would also be crippled, which, however, is not confirmed by experience.

It would perhaps be inappropriate to criticise Jaszlinsky on the grounds of his notions of heredity. Until the second half of the nineteenth century (Mendel) natural scientists had no clear concept of the transfer of genetic information, which is inherited from "enclosed" genes. Even Charles Darwin in his theory On the Origin of Species assumed completely incorrectly - that heredity works on the principle of blending inheritance. ${ }^{12}$ What surprises us is that Jaszlinsky did not also use a similar method of reasoning with

9 Jaszlinsky (1761: 552).

10 Jaszlinsky (1761: 553).

11 Jaszlinsky (1761: Section 552).

12 It is remarkable that blending heredity, that formed the cornerstone of Darwin's theory of evolution, thoroughly excludes the possibility of the successful persistance and spread of a mutation - incorrectly a "reduplication" - as that would subsequently be diluted to such a degree that in the following generations it would not have any influence at all. Here Darwin overlooked the consequence of his own mistake, and as Mario Livio states, it was blindness to his mistaken concept of heredity that made it possible to accept the theory as a whole. Livio (2014: p. 40). 
respect to heredity through an egg. A woman who is disabled (from birth) should inevitably produce disabled descendants, which again is not always confirmed by experience.

It seems that the reason for the rejection of this type of argument is Jaszlinsky's belief about the exclusive role of the egg. Igitur concludendum est: in omnium animalium ovis, sive ea vivipara sint, sive ovipara, foetum suis organis exilissimis effigiatum contineri, nec alio ad sui evolutionem egere, quam faecundatione, quae sit. ${ }^{13}$ Preformationists believed that the development of the new embryo only occurred due to the quantitative growth of organs already contained in the sex cell. Contrary to that, the advocates of epigenesis presumed a qualitative development of the embryo from the original amorphous rudimentary matter. ${ }^{14}$

Jaszlinsky then complicates his attitude: Quatenus seminalis substantiae pars vividior per tubos fallopianos in ovarium delata unum, vel plura ovula pervadit, primis futuri foetus staminibus in illo latentibus motum communicat ac efficit, ut haec se explicent, angeantur, ab ovario secernantur et ad uterum deferantur. ${ }^{15}$ It is thus not quite clear what Jaszlinsky actually believed was the role of sperm. It is evident that he does not occupy a purely Aristotelian position of self-fertilisation, but on the other hand, the question is whether he is an ovularist and also a kind of preformationist. He believes that the embryo only undergoes quantitative changes, those taking place according to its original make up prior even to fertilisation. Ovula autem conformiter ad dicta $n .532$ dicenda sunt potius in animalibus efformari dependenter ab organisatione specifica, quam initio mundi conditi in primorum animalium ovulis omnia iam comprehensa nuncque de uno animali in aliud solummodo transfusa. ${ }^{16}$ Jaszlinsky's theory thus resembles the remarkable concept of Charles Bonnet, although he does not mention him by name. In his battle against the theories of John Turberville Needham (Observations upon the Generation, Composition, and Decomposition of Animal and Vegetable Substances. London : [s.n.] 1749) and Georg Buffon (Histoire naturelle, générale et particulière 1749-1788) of spontaneous fertilisation and epigenesis, Bonnet argues from a preformationist point of view that the ovaria of the female already contain all the eggs of all the subsequent generations of her posterity and thus the female carries inside her all of her potential progeny in a more-or-less ready form ${ }^{17}$. In view of the problems brought about by this "box thesis" (the size of the mother's egg that contains the eggs of her descendants, that further contain the eggs of the descendants of her descendants.... as well as the obvious changes in the offspring in comparison with the parent), Bonnet slightly revised this attitude in his later works by allowing for the possibility of their development. $^{18}$

13 Jaszlinsky (1761: 554).

14 In 1759 (three years after the publication of Jaszlinsky's treatise) Caspar Friedrich Wolff published the work "Theoria generationis", according to which an adult organism develops from amorphous matter driven by a force called "vis essentialis".

15 Jaszlinsky (1761: 554).

16 Jaszlinsky (1761: 554).

17 Bonnet even managed to experimentallyconfirm the existence of clonal non-sexual reproduction of female aphids without impregnation by a male. Lawrence (2009).

18 In 1769 he wrote the work Palingénésie philosophique, where he presumed the development of organisms 
The reader may now be haunted by the question of whether this is not just an attempt to save the Aristotelian perception of the world. We assume that although the scholasticized teachings of Aristotle were generally accepted by the Jesuits as an authority and a point of departure for their research, Jaszlinsky clearly showed the courage to oppose Aristotle's theory of the origin of life, especially on the issue of self-fertilisation (which he completely rejected), but also on the issue of the inevitability of mixing of the male and female semen and their role in the origination of a new individual. Whereas Aristotle understood the sperm as a causa efficiens and menstrual blood (katamenia) - more correctly, this should be the egg $(!)^{19}$ - was understood as the causa materialis. The role of sperm was only to pass warmth to the egg (its role ends there) and thus to trigger the ontogenetic processes in the female embryo. That might signify the hereditary conditioning of the embryo by the female principle. Aristotle was aware of blending heredity, but he could not quite clearly explain (in a formal and purposeful way) the determining principle of this process. He assumed that it would be the amount of warmth which the sperm passes to the menstrual blood, thus "boiling" - perfecting it. ${ }^{20}$ The higher the degree of warmth, the more the embryo would realise its potential and the more it would approach the attributes of the father. A lesser amount of warmth would result in a lesser change to the menstrual blood, which means that the potential contained in the original katamenia would be brought to the fore.

Jaszlinsky steers away from this theory in both terminology and ideology and he enriches the original Aristotelian thinking with a certain version of preformationism, challenging it with contemporary theories and research. Although this text does not allow us to form an unequivocal opinion on the beliefs of Jaszlinsky in relation to the importance of sex elements in the origination and development of a live creature, it is obvious that his text is primarily focused on a comprehensive rejection of the theory of self-fertilisation - the origination of life from matter. ${ }^{21}$ In the final sections of the text we again encounter attempts to disprove the thesis of self-fertilisation and the origination of life from matter, whether in the form of worms, insects or Scottish geese and frogs. Jaszlinsky rejects myths related to this form of the origin of life as untrue and offers his own possible explanations. It is also interesting that he also ponders the way that parasites spread and survive within a human organism.

It is not quite clear what led a professor of Trnava University to prioritise this issue. We may assume, however, that one of his key motives may have been that he had come to terms

from the more simple towards the more complicated, through which he influenced others, for example, Ernst Haeckel.

19 It is interesting that Aristotle understands katamenia in a twofold sense, once only as a medium (727 and 27-30); and secondly as a type of semen (728 and 26-29). Lennox (2014).

20 The sperm were understood to be perfectly boiled-through blood, which is why for the fertility the katamenia must be boiled to goné.

21 No matter how extravagant the theory of self-fertilisation seems to us today, as Emanuel Rádl shows, even in the $19^{\text {th }}$ century there were a number of thinkers who believed in this theory and its modifications (Priestley's matter) - how else could they explain the origination of life without God? It seems that the discussion did not end even after experimental counter-arguments proposed by Louis Pasteur. Rádl (2006: pp. 222-226). 
with mechanicism and materialism. Descartes' philosophy (De la formation de l'animal) and even more Malebranche's occasionalism (Entretiens sur la métaphysique et sur la religion) enabled the birth of reflection on mechanistic preformation. Descartes' physics (also drawing on elements from the competing Gassendi atomism) and his theory of movement assumed that God created the world in such a way that he would no longer need to interfere with it and that matter reorganises itself thanks to the existence of the law of the conservation of momentum. As bodies are nothing more than mere ingenious mechanisms, for new mechanisms to originate it is sufficient to reorganise the individual parts of matter. In a response to Descartes, Malebranche said that "At the time of the Creation ... he constructed animals and plants for all future generations; he established the laws of motion that were necessary to make them grow. Now he rests, for he does nothing other than follow these laws". ${ }^{22}$ Thus, matter is not capable of originating life, and if life originates, it is because God created all creatures beforehand in such a way that they contained (as matter is infinitely divisible) all their future generations. It was an interesting way of bolstering creationism with empirical knowledge brought by contemporary science.

Malebranche was aware of the research of Malpighi, Swammerdam and Grew which on a microscopic level demonstrated the clear existence of the basic forms of organs at a very early stage in the development of the embryo (chicken, frog). Jaszlinsky does not quote them, but uses very similar arguments taken from the research of William Harvey and Alexis Littré (Observanions sur les ovaires (1701) and Diversé observations anatomiques (1732)). Nor does he quote the research of John Turberville Needham - an English naturalist and Catholic priest who through his own experiments demonstrated self-fertilisation and the birth of life from the vegetative forces of matter. ${ }^{23}$ However, he does make reference to very similar experiments, as well as metaphysical and teleological arguments (regarding the existence and number of sperm), in a similar way to Haller (regarding the number of types of wings and extremities) in opposition to Buffon.

\section{Conclusion}

As Shirley A. Roe points out, it was the effort to come to terms with both tendencies (mechanicism and materialism) that was the main reason for the origination of the various animisms and vitalisms in the middle of the $18^{\text {th }}$ century. ${ }^{24}$ While in Britain this effort resulted in the dominance of Newtonian physiology, in the case of Jaszlinsky, who was apparently familiar with and even lectured on Newtonian physics, we cannot confirm he followed in this kind of direction (the self-organisation of living matter on the basis of some gravitational force). However, we can clearly see that he maintained a dialogue with the most current theories and theses and tried to process them within

22 Malebranche (1958-: 12, p. 264). Quoted acc. to: Roe (2003: p. 407).

23 As Lazzaro Spallanzani pointed out, Needham's experiments suffered from a lack of thoroughness. His results, after the introduction of a comparative method and a meticulous examination of the variables (meat in a sealed vessel, cooked meat and overcooked meat), were disproved by Spallazani.

24 Roe (2003: pp. 48, 404). 
his perception of the world. It is understandable that, in striving for the idea of a unity of knowledge, he accepts the results of the observations and experiments of other scientists, attempting to include and explain them through the complex of arguments of his existing paradigm. That was not only driven by an economy of thought (it is simpler to incorporate new facts within the accepted knowledge than to modify the whole platform and thus all knowledge), but especially due to the belief that "Science does not only mean knowledge through causes but also knowing why and to what extent a cause is a cause." ${ }^{25}$ And it is exactly here, in his courage to modify the theses and points of departure of his predecessors, from Aristotle onwards, and align them with the research of his contemporaries and the most recent information, that Jaszlinsky proves his open mindedness and his effort to seek the truth within the boundaries of contemporary thought.

\section{Bibliography}

Blair, A. (2008). Natural Philosophy. In K. Park, \& L. Datson (Eds.), The Cambridge History of Science, 3: Early Modern Science. Cambridge: University Press.

Bonnet, Ch. (1672). Contemplation de la Nature. Amsterdam: Marc-Michel Ray.

Blum, P. R. (2012). Studies of Early Modern Aristotelianism. Leiden - Boston: Brill.

Buffon, G. (1766). Histoire Naturelle, générale et particulière, avec la description du Cabinet du Roi, Tome Quatorzième. Paris: Imprimerie royale.

Démuth, A., \& Juríková, E. (2016). Andrej Jaslinský a jeho Základy fyziky. In K. Karabová (Ed.), Antológia z diel profesorov pôsobiacich na Trnauskej univerzite (1635-1777) (pp. 63-94). Trnava: Trnavská univerzita.

Hartsoecker, N. (1694). Essai de dioptrique. Paris.

Harvey, W. (1651). Anatomical exercitations concerning the generation of living creatures to which are added particular discourses of births and of conceptions. London: apud James Young.

Hološová, A., \& Žažová, H. (2013). History of the Observatory at the University of Trnava 1756 - 1785. Trnava: Trnavská univerzita.

Jaszlinsky, A. (1761). Institutionum physicae pars altera seu physica particularis in usum discipulorum concinnata. Tyrnaviae: Typis academicis Societatis Jesu.

Kopecký, Š. (2014). The Faculty of Medicine 1769-1777. In J. Šimončič, \& A. Hološová (Eds.), The History of Trnava University 1635-1777 / 1992-2012 (pp. 269-277). Trnava: Typi Universitatis Tyrnaviensis.

Lawrence, C. R. (2009). Charles Bonnet (1720-1793). Embryo Project Encyclopedia [retrieved 24.09.2021 from http://embryo.asu.edu/handle/10776/1745].

Leeuwenhoek, A. (1677). De Natis e semine genital Animaculis. Letter to the Royal Society. In Philosophical Transactions, p. 1040-1042.

Leibniz, W. G. (1720). Lehr-Sätze über die Monadologie, ingleichen von Gott und seiner Existentz, seinen Eigenschafften und von der Seele des Menschen etc. wie auch Dessen letzte Vertheidigung seines Systematis Harmoniae praestabilitae wider die Einwürffe des Herrn Bayle. Frankfurt - Leipzig - Jena: Meyers sel. Witwe Buchhandlung.

25 Blum (2012: p. 129). 
Lennox, J. (2014). Aristotle's Biology. In E. N. Zalta (Ed.), The Stanford Encyclopedia of Philosophy. Spring Edition [retrieved 24.09.2021 from http://plato.stanford.edu/archives/spr2014/entries/aristotle-biology].

Livio, M. (2014). Brilliant Blunders: From Darwin to Einstein - Colossal Mistakes by Great Scientists That Changed Our Understanding of Life and the Universe [Czech translation: Kadlecová, E. Geniálni omyly]. Brno: CPress.

Malebranche, N. (1958-). Oeuvres completes (ed. A. Robinet; Vol. 12: p. 264). Paris: Librairie Philosophique J. Vrin.

Malpighi, M. (1686). De formation pulli in ovo. In Opera Omnia. London: apud Robertum Scott.

McClellan III, J. (2003). Scientific Institutions and the Organization of Science. In R. Porter (Ed.), The Cambridge History of Science, 4: Eighteenth-Century Science (pp. 87-106). Cambridge: Cambridge University Press.

Needham, J. T. (1749). Observations upon the Generation, Composition, and Decomposition of Animal and Vegetable Substances. London : [s.n.]

Needham, J. (1959). A History of Embryology. New York: Abelard-Schuman.

Pivovarčiová, L., \& Schwarc, E. (2014). The University Pharmacy. In J. Šimončič, \& A. Hološová (Eds.), The History of Trnava University 1635-1777 / 1992-2012 (pp. 269-277). Trnava: Typi Universitatis Tyrnaviensis.

Rádl, E. (2006). Dějiny biologických teorií novověku (Vol. II). Praha: Academia.

Roe, S. A. (2003). The Live Sciences. In R. Porter (Ed.), The Cambridge History of Science, 4: Eighteenth-Century Science. Cambridge: Cambridge University Press.

Swammerdam, J. (1672). Miraculum nature, sive, Uteri muliebris fabrica. Lugduni Batavorum [Leiden]: apud Severinum Matthæi. Zborovjan, M. (2014). The Botanical Garden of the Faculty of Medicine 1771-1777. In J. Šimončič, \& A. Hološová (Eds.), The History of Trnava University 1635-1777 / 1992-2012 (pp. 279-285). Trnava: Typi Universitatis Tyrnaviensis.

Prof. Mgr. Mgr. Andrej Démuth, PhD. / andrej.demuth@uniba.sk

Department of Theory and Philosophy of Law

Comenius University in Bratislava, Faculty of Law

Šafárikovo nám. 6, P.O.BOX 313, 81000 Bratislava, Slovak Republic

Doc. Mgr. Erika Juríková, PhD. / erika.jurikova@truni.sk

Department of Classical Languages

Trnava University, Faculty of Philosophy

Hornopotočná 23, 91843 Trnava, Slovak Republic

This work can be used in accordance with the Creative Commons BY-SA 4.0 International license terms and conditions (https://creativecommons.org/licenses/by-sa/4.0/legalcode). This does not apply to works or elements (such as image or photographs) that are used in the work under a contractual license or exception or limitation to relevant rights 
